\title{
Soil Fungistasis: Role of the Microbial Nutrient Sink and of Fungistatic Substances in Two Soils
}

\author{
By P. R. BRISTOW* AND J. L. LOCKWOOD \\ Department of Botany and Plant Pathology, Michigan State University, \\ East Lansing, Michigan 48824, U.S.A.
}

(Received 3I January 1975; revised I April 1975)

\begin{abstract}
SUMMARY
Sensitivity of conidia of Cochliobolus victoriae to fungistasis decreased markedly following incubation on moist sand for at least $\mathrm{I} h$. Germination was greater on Conover loam or on sand being leached with water than on an alkaline clay loam soil known to produce a volatile fungistatic substance. Evolution of ${ }^{14} \mathrm{CO}_{2}$ began within 3 min after $\left[{ }^{14} \mathrm{C}\right]$ glucose was applied to the soils; the rate of ${ }^{14} \mathrm{CO}_{2}$ evolution was faster with Conover loam. Germination of Thielaviopsis basicola conidia per unit of glucose remaining in agar discs initially containing $0.1 \%$ glucose, was lower for discs incubated on the clay loam soil than on Conover loam, and was greatest on a bed of sand undergoing aqueous leaching. Germination of ascospores of Neurospora tetrasperma and conidia of $C$. victoriae was suppressed on discs of washed, Purified Agar or polyacrylamide gel incubated on or over the clay loam soil, but no suppression resulted when discs were incubated on Conover loam. Extensive aeration of either soil did not remove its fungistatic effect. Fungistasis in Conover loam appears to be caused primarily by nutrient deprivation, whereas volatile fungistatic substances may play a major role in the clay loam soil.
\end{abstract}

\section{INTRODUCTION}

Ko \& Lockwood ( 1967 ) proposed that soil is maintained in a fungistatic state by continuous microbial competition for the minute qualities of nutrients that may become available, and which are required for germination by many spores. However, spores and sclerotia of certain fungi will germinate in water alone, but only sparsely in soil. Germination of such propagules is also suppressed when incubated on sand undergoing aqueous leaching in a system designed to impose upon the propagules a diffusion stress similar to that imposed in soil through microbial activity (Ko \& Lockwood, 1967; Hsu \& Lockwood, 1973; Bristow \& Lockwood, 1975). Evidence provided by Hora \& Baker (1970) suggests the involvement of a volatile fungistatic factor in addition to nutrient deprivation. Ammonia has been identified as the volatile fungistatic factor in two alkaline soils (Ko, Hora \& Herlicska, 1974), and ethylene was reported to be the active substance in several Australian soils (Smith, 1973). This research was undertaken to evaluate the role of the microbial nutrient sink in soil fungistasis in the light of recent reports of volatile inhibitory materials.

* Present address: Department of Plant Pathology, University of Missouri, Columbia, Missouri 6520I, U.S.A. 


\section{METHODS}

Fungal propagules. Conidia of Cochliobolus victoriae were cultured, collected, and labelled with ${ }^{14} \mathrm{C}$ as previously described (Bristow \& Lockwood, 1975). Thielaviopsis basicola endoconidia and Neurospora tetrasperma ascospores were produced as described by Ko \& Lockwood (1967); the latter were heat-activated at $58{ }^{\circ} \mathrm{C}$ for $20 \mathrm{~min}$. Conidial suspensions were washed three times by centrifugation in glass-distilled water at $4{ }^{\circ} \mathrm{C}$.

Spore germination assays. Conover loam soil (Steiner \& Lockwood, 1969) and an alkaline ( $\mathrm{pH} \mathrm{8.3)} \mathrm{clay} \mathrm{loam} \mathrm{soil} \mathrm{from} \mathrm{Colorado} \mathrm{(Hora} \mathrm{\&} \mathrm{Baker,} \mathrm{1970),} \mathrm{both} \mathrm{previously} \mathrm{sieved} \mathrm{and}$ air-dried, were re-moistened to 27 and $33 \%(\mathrm{w} / \mathrm{w})$ moisture, respectively, placed in plastic Petri dishes $(90 \times 15 \mathrm{~mm}, 50 \mathrm{~g}$ air-dried soil/dish), and the surface smoothed. Soil plates were incubated for $24 \mathrm{~h}$ before use. Sterile soil was obtained by autoclaving plates at I2I ${ }^{\circ} \mathrm{C}$ for $30 \mathrm{~min}$, then adding sufficient sterile water to return the soil moisture to its original level. A system was used which provides a nutrient depletion sink similar to the microbial nutrient sink of natural soil, through aqueous leaching of a bed of sand bearing propagules on membrane filters (Hsu \& Lockwood, 1973; Bristow \& Lockwood, 1975). The volume of water held by the sand bed at saturation was $33 \mathrm{ml}$. The flow rate of glass-distilled water or dilute potassium phosphate buffer $\left(0.025 \mathrm{M}, \mathrm{pH} 7^{\circ} \mathrm{0}\right)$ through the sand (10 to $80 \mathrm{ml} / \mathrm{h}$ ) was metered with a peristaltic pump (Manostat Corp., New York, N.Y., U.S.A.). Acidwashed silica sand saturated with water or buffer solution provided non-leached controls.

Inhibition due to the nutrient sink was differentiated from that caused by another fungistatic factor in soil using discs $2.5 \times 9.0 \mathrm{~mm}$ diam cut from plates of $2 \%$ Purified Agar (Difco) containing $0 . \mathrm{I} \%(\mathrm{w} / \mathrm{v})$ glucose. In addition, half the discs also contained $\left[{ }^{14} \mathrm{C}\right]$ glucose (3000 c.p.m./disc). The discs were incubated on the two soils, in the leaching system, and on water-saturated sand for intervals up to $24 \mathrm{~h}$. Upon removal from the above treatments, the concentration of glucose remaining in the discs was determined radiochemically; discs without $\left[{ }^{14} \mathrm{C}\right]$ glucose were bioassayed by inoculating them with conidia of $T$. basicola and incubating at $24{ }^{\circ} \mathrm{C}$ for $\mathrm{I} 2 \mathrm{~h}$. Discs with glucose concentrations ranging from $0 \cdot \mathrm{I}$ to $1000 \mu \mathrm{g} /$ $\mathrm{ml}$ served to establish a standard curve for germination. Some agar discs were prepared at various $\mathrm{pH}$ values with $0 \cdot \mathrm{I} \mathrm{M}$-potassium phosphate.

Polyacrylamide gel (PAG) was prepared according to the procedure of Bishop, Claybrook $\&$ Spiegelman (1967). Discs were $2.5 \mathrm{~mm}$ thick $\times 9.0 \mathrm{~mm}$ diam. They were soaked in buffer solution, changed daily, for 7 days to remove toxic materials. The discs were autoclaved before use.

Spores on agar and PAG discs were separated from soils and sand by Nuclepore membrane filters $(0.4 \mu \mathrm{m}$ pore size; General Electric Corp., Pleasantville, California, U.S.A.). All germination experiments were done at $25 \pm 2{ }^{\circ} \mathrm{C}$. Germination was determined microscopically, after staining (Bristow \& Lockwood, 1975).

Radiochemical purity of $\left[{ }^{14} \mathrm{C}\right]$ glucose in agar discs. After incubation on soil, duplicate agar discs, each initially containing 200000 c.p.m., were eluted by shaking in $\mathrm{I} \cdot 5 \mathrm{ml}$ water at $35^{\circ} \mathrm{C}$ for $\mathrm{I} \mathrm{h}$ or dissolving them in $2.0 \mathrm{ml}$ of $\mathrm{I} \cdot 0 \mathrm{M}-\mathrm{HCl}$ at $100{ }^{\circ} \mathrm{C}$ for $20 \mathrm{~min}$. A sample $(0.1 \mathrm{ml})$ of the eluate was streaked on Whatman No. I chromatography paper; another $0^{\circ}$ I $\mathrm{ml}$ sample of the $\mathrm{HCl}$ solution was spotted on a silica gel GF t.l.c. plate $(250 \mu \mathrm{m}$; Analtech Inc., Newark, Delaware, U.S.A.). Paper chromatograms were developed by ascending chromatography in $n$-butanol- $n$-propanol-water ( $4: \mathrm{I}: \mathrm{I}$, by vol.). Triplicate t.l.c. plates were run in the following solvent systems : (i) $t$-butanol- $n$-propanol-water ( $4: \mathrm{I}: \mathrm{I}$, by vol.); (ii) $n$-butanol-acetone-water (4:5:I, by vol.); (iii) methyl ethyl ketone-acetic acid-water (3: I: I, by vol.). Radioactive bands on paper chromatograms were detected with a Packard 
radio-chromatogram scanner (model 720I); spots on t.1.c. plates were located by exposing the plates to X-ray film for 6 weeks at $6{ }^{\circ} \mathrm{C}$. Thin-layer chromatography plates were also developed by spraying with $50 \% \mathrm{H}_{2} \mathrm{SO}_{4}$ and then charring at $120^{\circ} \mathrm{C}$.

Metabolism of glucose and spore exudates by soil micro-organisms. Two $\mu \mathrm{Ci}$ ( $72 \mu \mathrm{g}$ glucose) of $\left[{ }^{14} \mathrm{C}\right]$ glucose were applied to the smoothed surface of soil in a dish with an air-tight lid fitted with inlet and outlet tubes. Moistened air was passed over the soil at a rate of about $3 \mathrm{l} / \mathrm{h}$, then trapped in $2.0 \mathrm{ml}$ ethanolamine solution (methyl cellosolve-ethanolamine; $7: 3$, $\mathrm{v} / \mathrm{v}$ ) in a scintillation vial. Respired ${ }^{14} \mathrm{CO}_{2}$ was collected in the same manner from soil suspensions ( $\mathrm{I} \cdot \mathrm{O}$ air-dried soil in $\mathrm{I} \cdot 0 \mathrm{ml}$ water) containing $\mathrm{I} \cdot 0 \mathrm{ml}$ of a concentrated exudate from ${ }^{14} \mathrm{C}$-labelled conidia of $C$. victoriae, through which moistened air was bubbled.

Spore exudate was collected from a suspension containing 5000 conidia/ml incubated with stirring for $\mathrm{I} h$. The conidia were removed by membrane filtration and the exudate was concentrated under vacuum to one-eightieth its original volume. Several unidentified bacterial isolates obtained from both soils were cultured in nutrient broth, and washed by centrifugation at $2{ }^{\circ} \mathrm{C}$; the final concentration of each in distilled water was adjusted to $E_{500}=0.40$ photospectrometrically. Cell suspension ( $\mathrm{r} \mathrm{ml}$ ) was added to an equal volume of concentrated radioactive spore exudate. Every $15 \mathrm{~min}$, bacterial cells in a portion of the mixture were recovered and washed on a Nuclepore filter with $10 \mathrm{ml}$ of a detergent solution, $0.1 \%$ Tergitol TMN, followed by the same volume of water.

Radioactivity in agar discs, bacterial cells, ethanolamine traps and concentrated spore exudate $(\mathrm{I} \cdot 0 \mathrm{ml})$ was determined in scintillation fluid (Bray, 1960) by means of a Packard Tri-Carb spectrometer.

Aseptic procedures were used unless otherwise indicated. All experiments were run in duplicate and were repeated at least once.

\section{RESULTS}

Time when C. victoriae conidia become insensitive to fungistasis

Fungal spores that require an exogenous source of nutrients for germination are inhibited when exposed to soil, moist sand, or leached sand at any stage during germination, or during growth following germination (Steiner \& Lockwood, 1969; Hsu \& Lockwood, 1973). To determine whether the same is true for nutrient-independent propagules, unwashed conidia of $C$. victoriae were first incubated on water-saturated sand for intervals of up to $6 \mathrm{~h}$, then transferred to water-saturated sand, Conover loam, the clay loam, or to the leaching system for $4 \mathrm{~h}$ additional incubation. After $\mathrm{I} \mathrm{h}$ prior exposure to water-saturated sand, conidial germination was increased on both soils and on the leaching system (Table I). After $\mathrm{I} \cdot 5 \mathrm{~h}$, conidia were no longer sensitive to fungistasis on Conover loam or the leaching system, whereas those incubated on clay loam did not become insensitive until there had been $4 \mathrm{~h}$ prior incubation on water-saturated sand. Thus, the clay loam was more inhibitory than Conover loam. The decrease in sensitivity to fungistasis following brief prior exposure of spores to water indicates that the factor(s) responsible for fungistasis in soil must act upon conidia of this fungus early in the germination process.

\section{Establishment of the microbial nutrient sink}

Radioactive $\mathrm{CO}_{2}$ was detected within 3 min after the application of $\left[{ }^{4} \mathrm{C}\right]$ glucose to Conover loam or the clay loam; 7 and $3 \%$, respectively, of the $2 \cdot 0 \mu \mathrm{Ci}\left[{ }^{14} \mathrm{C}\right]$ glucose applied was respired in $4 \mathrm{~h}$ (Fig. I). No respiration occurred when sterile soil was used. When $\left[{ }^{14} \mathrm{C}\right]$ glucose $(0.05 \mu \mathrm{Ci} / \mathrm{ml})$ was added to soil suspensions, nearly $20 \%$ of the radioactivity 
Table I. Germination of C. victoriae conidia first incubated on water-saturated sand for o to $6 \mathrm{~h}$, then incubated for four additional hours on water-saturated sand, the leaching system, Conover loam soil, or the clay loam soil

\begin{tabular}{|c|c|c|c|c|c|c|}
\hline \multicolumn{2}{|c|}{ Water-saturated sand } & \multicolumn{4}{|c|}{ (Germination $\%$ ) } & \multirow[b]{2}{*}{$\begin{array}{c}\text { LSD }^{*} \\
(P=0.05)\end{array}$} \\
\hline $\begin{array}{l}\text { Incubation time } \\
\text { before transfer } \\
\text { (h) }\end{array}$ & $\begin{array}{c}\text { Germination } \\
\text { at time of transfer } \\
(\%)\end{array}$ & $\begin{array}{l}\text { Water- } \\
\text { saturated } \\
\text { sand }\end{array}$ & $\begin{array}{l}\text { Leaching } \\
\text { system }\end{array}$ & $\begin{array}{c}\text { Conover } \\
\text { loam } \\
\text { soil }\end{array}$ & $\begin{array}{c}\text { Clay } \\
\text { loam } \\
\text { soil }\end{array}$ & \\
\hline 0 & 0 & 60 & $3 I$ & I4 & 7 & I 8 \\
\hline 0.5 & 0 & 65 & 17 & 14 & 9 & 8 \\
\hline$I \cdot O$ & 0 & 67 & 46 & 46 & 30 & IO \\
\hline $1 \cdot 5$ & 22 & 70 & 64 & 72 & 43 & 15 \\
\hline $2 \cdot 0$ & 39 & 73 & 70 & 71 & 50 & 5 \\
\hline $3 \cdot 0$ & 58 & 74 & 70 & 75 & 69 & II \\
\hline 4.0 & $7 \mathrm{I}$ & 75 & 73 & 74 & 67 & 9 \\
\hline $6 \cdot 0$ & 74 & 77 & 77 & 73 & 71 & 12 \\
\hline
\end{tabular}

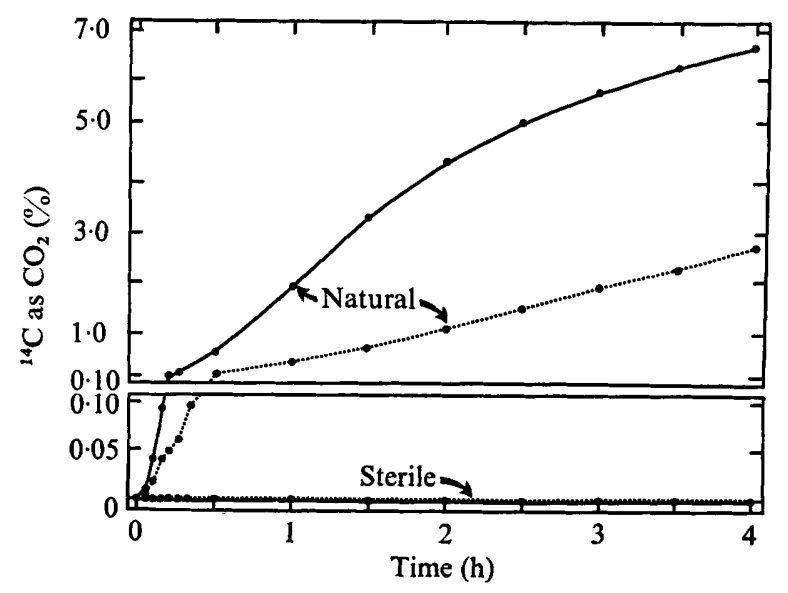

Fig. I. Evolution of ${ }^{14} \mathrm{CO}_{2}$ from natural and sterile Conover loam $(\rightarrow$ and from a clay loam soil $(\cdots)$ following the application of $\left[{ }^{14} \mathrm{C}\right]$ glucose to the soil surface.

was evolved as ${ }^{14} \mathrm{CO}_{2}$ from Conover loam, whereas only $12 \%$ was evolved from clay loam, after $4 \mathrm{~h}$. When concentrated radioactive spore exudate was applied to soil suspensions, ${ }^{14} \mathrm{CO}_{2}$ was detected within $\mathrm{I}_{5} \mathrm{~min} ; 3.0$ and $\mathrm{I} \cdot 2 \%$, respectively, of the available ${ }^{14} \mathrm{C}$ (I050 c.p.m.) was evolved by the two soil suspensions in $4 \mathrm{~h}$.

Two bacterial isolates from each soil accumulated radioactivity within $15 \mathrm{~min}$ when incubated in the concentrated spore exudate. Two of the isolates had accumulated about $6 \%$ of the radioactivity available within $\mathrm{I} h$. Populations of bacteria and actinomycetes, as estimated by soil dilution plates on soil agar (Farley \& Lockwood, I968) and chitin agar (Lingappa \& Lockwood, 1962) respectively, were similar in the clay loam and Conover loam. However, the fungal population, estimated on acidified PDA (Steiner \& Watson, I965) was 30 times greater $\left(7 \cdot 0 \times \mathrm{IO}^{4} / \mathrm{g}\right.$ air-dried soil, compared with $\left.2 \cdot \mathrm{I} \times 10^{3} / \mathrm{g}\right)$ in Conover loam. Thus, the greater microbial nutrient sink in Conover loam may be attributed to the higher fungal numbers as well as to greater microbial activity. 


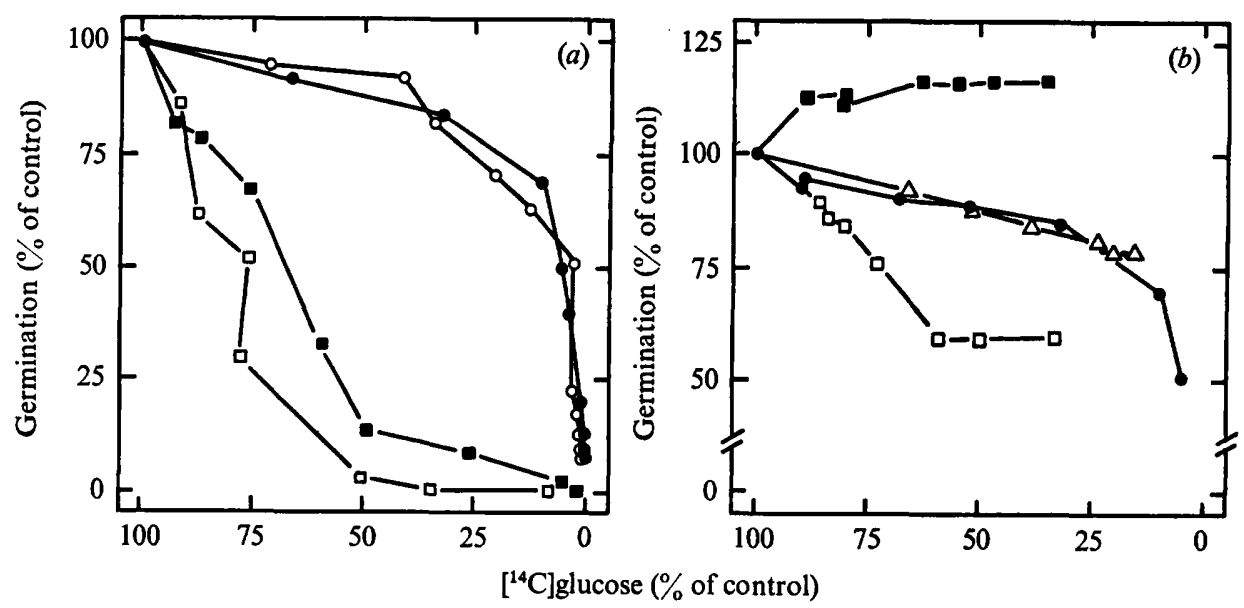

Fig. 2. Germination of Thielaviopsis basicola conidia on Purified Agar discs, initially containing $0.1 \%$ glucose, after incubation $(a)$ on two natural soils and in the leaching system, and $(b)$ on sterile soils and on water-saturated sand. Discs initially containing $3000 \mathrm{c.p.m}$. of $\left[{ }^{14} \mathrm{C}\right] \mathrm{glucose} / \mathrm{disc}$ were used to determine the percentage of glucose remaining. The 'standard' curve is germination on discs containing a range of glucose concentrations from 0.00001 to $0.1 \%$. Natural $(a)$ or sterile (b) clay loam; $\boldsymbol{\square}$, natural $(a)$ or sterile $(b)$ Conover loam; $O$, model system; $\triangle$, water saturated sand; , standard.

\section{Role of the nutrient sink in fungistasis}

Germination of $T$. basicola conidia per unit of glucose was the same on agar discs removed from the leaching system (where the only fungistatic factor is nutrient deprivation) as on standard discs (Fig. 2a). However, germination on discs incubated on either soil was less than that predicted by their glucose concentration. Inhibition by factors other than nutrient deprivation was shown within 30 min on both soils. Delaying the bioassay of discs from either soil for $12 \mathrm{~h}$ did not reduce the inhibition, indicating that it was not due to highly volatile or unstable compounds. Sterile Conover loam stimulated germination on discs over that of discs incubated on water-saturated sand, whereas autoclaving the clay loam reduced its inhibitory effect only slightly (Fig. $2 b$ ). Carbohydrates and amino acids released during autoclaving were nearly the same for the two soils, although concentrations before autoclaving were much higher in the clay loam. No radioactive spots other than glucose were identified on paper or thin-layer chromatograms. Furthermore, no spots other than those present in untreated discs appeared on charred t.l.c. plates.

Soil, I to 2 weeks after amendment with cellulose, was more fungistatic than unamended soil (Adams, Lewis \& Papavizas, 1968). The elevated level of fungistasis was related to an increased rate of microbial utilization of glucose added to soil, but there is also the possibility of greater amounts of inhibitory materials in the amended soil. Conover loam was amended with $2 \%(\mathrm{w} / \mathrm{w})$ alfalfa hay particles $(420 \mu \mathrm{m})$ and incubated for 2 weeks. Glucose half-life in Purified Agar discs incubated on amended soil was $4.0 \mathrm{~h}$, compared with $7.0 \mathrm{~h}$ on unamended soil. There was no decrease in the germination of $T$. basicola conidia per unit glucose remaining in discs incubated on amended as compared with non-amended soil, indicating that increased microbial competition for nutrients was the cause for the elevated fungistasis.

\section{Fungistatic substances in soil}

Discs of PAG or of Purified Agar, first incubated in the leaching system for $24 \mathrm{~h}$ to render them as nutrient-free as possible, were incubated in the leaching system, in soil, or placed above soil on a glass slide for $12 \mathrm{~h}$ before inoculation. After inoculation, discs were left 
Table 2. Germination of C. victoriae conidia on Purified Agar or polyacrylamide gel discs first incubated on or over clay loam or Conover loam, or on the leaching system for $12 h$ before inoculation; then either left in situ or transferred to an empty Petri dish for $8 \mathrm{~h}$ additional incubation

\begin{tabular}{|c|c|c|c|c|c|c|c|}
\hline \multicolumn{3}{|l|}{ 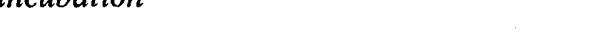 } & \multicolumn{4}{|c|}{ Germination (\%) } & \multirow[b]{2}{*}{$\begin{array}{c}\text { LSD } \\
(P=0.05)\end{array}$} \\
\hline Type of disc & First incubation & $\begin{array}{l}\text { Second } \\
\text { incubation }\end{array}$ & Control* & $\begin{array}{l}\text { Clay } \\
\text { loam }\end{array}$ & $\begin{array}{c}\text { Conover } \\
\text { loam }\end{array}$ & $\begin{array}{c}\text { Leaching } \\
\text { system }\end{array}$ & \\
\hline \multirow[t]{2}{*}{ Purified agar } & $\begin{array}{l}\text { Soil or leaching } \\
\text { system }\end{array}$ & $\begin{array}{l}\text { In situ } \\
\text { Petri dish }\end{array}$ & $\begin{array}{l}70 \\
70\end{array}$ & $\begin{array}{l}14 \\
56\end{array}$ & $\begin{array}{l}49 \\
7 \mathrm{I}\end{array}$ & $\begin{array}{l}54 \\
73\end{array}$ & $\begin{array}{l}15 \\
12\end{array}$ \\
\hline & Over soil & $\begin{array}{l}\text { In situ } \\
\text { Petri dish }\end{array}$ & $\begin{array}{l}77 \\
77\end{array}$ & $\begin{array}{l}18 \\
58\end{array}$ & $\begin{array}{l}81 \\
78\end{array}$ & - & $\begin{array}{l}18 \\
16\end{array}$ \\
\hline \multirow[t]{2}{*}{$\begin{array}{l}\text { Polyacrylamide } \\
\text { gel }\end{array}$} & $\begin{array}{l}\text { Soil or leaching } \\
\text { system }\end{array}$ & $\begin{array}{l}\text { In situ } \\
\text { Petri dish }\end{array}$ & $\begin{array}{l}76 \\
76\end{array}$ & $\begin{array}{r}2 \\
6 I\end{array}$ & $\begin{array}{l}53 \\
87\end{array}$ & $\begin{array}{l}57 \\
74\end{array}$ & $\begin{array}{l}15 \\
16\end{array}$ \\
\hline & Over soil & $\begin{array}{l}\text { In situ } \\
\text { Petri dish }\end{array}$ & $\begin{array}{l}83 \\
83\end{array}$ & $\begin{array}{l}79 \\
79\end{array}$ & $\begin{array}{l}82 \\
80\end{array}$ & - & $\begin{array}{l}16 \\
17\end{array}$ \\
\hline \multicolumn{2}{|c|}{$\operatorname{LSD}(P=0.05)$} & & I6 & 13 & 16 & 14 & - \\
\hline
\end{tabular}

* Controls were untreated discs incubated in a Petri dish.

Table 3. Germination of Neurospora tetrasperma ascospores on Purified Agar or polyacrylamide gel discs first incubated on or over clay loam or Conover loam, or on the leaching system for 12 h before inoculation; then either left in situ or transferred to an empty Petri dish for $8 h$ additional incubation

\begin{tabular}{|c|c|c|c|c|c|c|c|}
\hline \multirow[b]{2}{*}{ Type of discs } & \multirow[b]{2}{*}{ First incubation } & \multirow[b]{2}{*}{$\begin{array}{c}\text { Second } \\
\text { incubation }\end{array}$} & \multicolumn{4}{|c|}{ Germination ( $\%$ ) } & \multirow[b]{2}{*}{$\begin{array}{c}\text { LSD } \\
(P=0.05)\end{array}$} \\
\hline & & & Control* & $\begin{array}{l}\text { Clay } \\
\text { loam }\end{array}$ & $\begin{array}{l}\text { Conover } \\
\text { loam }\end{array}$ & $\begin{array}{l}\text { Leaching } \\
\text { system }\end{array}$ & \\
\hline \multirow[t]{2}{*}{ Purified agar } & $\begin{array}{l}\text { Soil or leaching } \\
\text { system }\end{array}$ & $\begin{array}{l}\text { In situ } \\
\text { Petri dish }\end{array}$ & $\begin{array}{l}81 \\
8 I\end{array}$ & $\begin{array}{r}0 \\
15\end{array}$ & $\begin{array}{l}79 \\
77\end{array}$ & $\begin{array}{l}79 \\
72\end{array}$ & $\begin{array}{r}8 \\
13\end{array}$ \\
\hline & Over soil & $\begin{array}{l}\text { In situ } \\
\text { Petri dish }\end{array}$ & $\begin{array}{l}75 \\
75\end{array}$ & $\begin{array}{r}6 \\
21\end{array}$ & $\begin{array}{l}80 \\
75\end{array}$ & - & $\begin{array}{r}10 \\
9\end{array}$ \\
\hline \multirow[t]{2}{*}{$\begin{array}{l}\text { Polyacrylamide } \\
\text { gel }\end{array}$} & Soil & $\begin{array}{l}\text { In situ } \\
\text { Petri dish }\end{array}$ & $\begin{array}{l}79 \\
79\end{array}$ & $\begin{array}{r}9 \\
60\end{array}$ & $\begin{array}{l}72 \\
77\end{array}$ & - & $\begin{array}{r}9 \\
12\end{array}$ \\
\hline & Over soil & $\begin{array}{l}\text { In situ } \\
\text { Petri dish }\end{array}$ & $\begin{array}{l}78 \\
78\end{array}$ & $\begin{array}{l}77 \\
70\end{array}$ & $\begin{array}{l}82 \\
76\end{array}$ & - & $\begin{array}{l}\text { IO } \\
\text { I I }\end{array}$ \\
\hline \multicolumn{2}{|c|}{$\operatorname{LSD}(P=0.05)$} & & 8 & I I & 9 & 12 & 一 \\
\hline
\end{tabular}

in situ, or placed in an empty Petri dish for an additional $8 \mathrm{~h}$ of incubation. Discs of PAG or Purified Agar, incubated on the leaching system or on either soil throughout the experiment, reduced the germination of conidia of $C$. victoriae, particularly on the clay loam (Table 2). However, when discs were transferred to an empty Petri dish for bioassay, only those that were first incubated on the clay loam soil caused inhibition, and this inhibition was less than on discs continuously incubated on the clay loam. When discs were incubated continuously over soil, inhibition occurred only with discs of Purified Agar incubated over the clay loam. Results were similar with activated ascospores of $N$. tetrasperma, except that their germination was inhibited only with the clay loam treatments (Table 3).

Discs of Purified Agar were similarly incubated on either of the two soils or the leaching system for 0 to $24 \mathrm{~h}$, and then removed and amended to contain 0.005 or $0.1 \%$ glucose. When bioassayed with conidia of $T$. basicola, only discs that had been incubated on the clay 
Table 4. Germination of Thielaviopsis basicola conidia on Purified Agar discs first incubated on the leaching system, on Conover loam, or on the clay loam; then transferred to a Petri dish and amended to contain 0.1 or $0.005 \%$ glucose before inoculation. Inoculated discs were incubated for $\mathrm{I} 2 h$

$\begin{array}{cccccc}\text { Treatment } & \begin{array}{c}\text { Treatment } \\ \text { time } \\ \text { (h) }\end{array} & \begin{array}{c}\text { Leaching } \\ \text { system }\end{array} & \begin{array}{c}\text { Conover } \\ \text { loam soil }\end{array} & \begin{array}{c}\text { Clay } \\ \text { loam soil }\end{array} & \begin{array}{c}\text { LSD } \\ (P=0.05)\end{array} \\ \text { Glucose (0.1 \%) } & 0 & 85 & 81 & 79 & 14 \\ & 4 & 78 & 80 & 68 & 13 \\ & 12 & 83 & 83 & 58 & 13 \\ \text { Glucose (0.0005\%) } & 24 & 78 & 76 & 48 & 16 \\ & 0 & 71 & 68 & 56 & .15 \\ & 42 & 70 & 68 & 47 & 13 \\ & 12 & 71 & 60 & 40 & 12 \\ & 24 & 67 & 37 & 26 & 15\end{array}$

Table 5. Germination of Thielaviopsis basicola conidia on glucose-amended agar discs incubated in the head space above clay loam soil, Conover loam soil, or water-saturated sand

$\begin{array}{ccccc}\begin{array}{c}\text { Glucose } \\ \begin{array}{c}\text { concentration } \\ (\mu \mathrm{g} / \mathrm{ml})\end{array}\end{array} & \begin{array}{c}\text { Clay } \\ \text { loam soil }\end{array} & \begin{array}{c}\text { Conover } \\ \text { loam soil }\end{array} & \begin{array}{c}\text { Water- } \\ \text { saturated } \\ \text { sand }\end{array} & \begin{array}{c}\text { LSD } \\ (P=0 \cdot 05)\end{array} \\ 0 & 20 & 29 & 25 & 10 \\ 0 \cdot 1 & 17 & 28 & 26 & 12 \\ \text { I } & 18 & 48 & 46 & 9 \\ \text { I0 } & 49 & 72 & 66 & 12 \\ 100 & 62 & 87 & 86 & 13 \\ 1000 & 67 & 85 & 90 & 16\end{array}$

loam soil for $\mathrm{I} 2 \mathrm{~h}$ or more reduced germination when amended with $0 . \mathrm{I} \%$ glucose (Table 4 ). However, there was about a $50 \%$ reducation in germ-tube lengths on discs incubated on Conover loam for $24 \mathrm{~h}$. When the glucose concentration in discs was brought to only $0.005 \%$, discs that had been on the clay loam showed greater suppression of germination than at $0.1 \%$ and required no prior incubation on the clay loam for expression of inhibition. Inhibition with Conover loam was shown only on discs incubated for $24 \mathrm{~h}$ on soil before amendment with $0.005 \%$ glucose.

Thus, results using agar and PAG discs confirmed the existence of volatile and non-volatile substances in the clay loam soil, but provided little or no evidence for their presence in Conover loam.

The low hydrogen ion concentration of the clay loam does not appear to be responsible for inhibition, as germination of $C$. victoriae conidia was unchanged on Purified Agar buffered to $\mathrm{pH}$ values ranging from 5 to 8 .

Agar discs amended with glucose at concentrations from 0 to $1000 \mu \mathrm{g} / \mathrm{ml}$ were incubated in the head space above either soil or water-saturated sand. At all concentrations of glucose, germination of $T$. basicola conidia was less when discs were incubated over the clay loam than over Conover loam or leached sand (Table 5). However, the presence of glucose partially annulled the effect of the volatile fungistatic factor emanating from the clay loam soil.

Numerous attempts to negate fungistasis by the removal of any volatile fungistatic factor 
which may have been present, failed. Moist air was passed over about $50 \mathrm{~g}$ of either soil at about $75 \mathrm{ml} / \mathrm{min}$, a rate sufficient to replace the air in the head space every two minutes. Conidia of $C$. victoriae on the soil surface did not germinate, although more than $75 \%$ of those on water-saturated sand, treated identically, germinated in $4 \mathrm{~h}$. Aerating re-moistened air-dried Conover loam and clay loam soils for one month did not allow any growth of indigenous moulds, and sclerotia of Sclerotium rolfsiifrom PDA cultures remained dormant on the surface of the soils. Sclerotia incubated on water-saturated sand controls germinated within 3 days. Passing moist air over the surface of Australian soils allowed copious mould growth and germination of $S$. rolfsii sclerotia (Smith, 1973).

\section{DISCUSSION}

Germination of nutrient-dependent spores is stopped at any stage by transfer from nutrientrich conditions to soil or the leaching system (Steiner \& Lockwood, 1969; Yoder \& Lockwood, 1973). However, in the experiments described here, a prior exposure to water resulted in greatly reduced sensitivity of spores of the nutrient-independent conidia of C. victoriae. Thus, the factors responsible for fungistasis in soil must act rapidly before the spore becomes insensitive. The microbial nutrient sink in soil was activated within minutes of the addition of glucose or spore exudates to soil.

Correlations between decreasing fungal spore germination and decreasing nutrients because of microbial utilization have been reported (Adams et al. 1968; Ko \& Lockwood, 1967; Steiner \& Lockwood, 1970). Results with glucose-impregnated agar discs indicated that nutrient deprivation may not be the only cause of fungistasis. However, in Conover loam the results were equivocal, since the unavoidable addition of glucose could have provided the energy needed for microbial synthesis of fungistatic substances. Failure to detect volatile or non-volatile inhibitory substances in Conover loam, or to remove the inhibition by aeration, suggests that the additional fungistatic factor observed is due to elevated local glucose concentrations in the soil. Since radioactive metabolites of glucose were not detected in the assay discs, glucose may have provided the energy required for their synthesis from organic matter in resistant soil. Lingappa \& Lockwood (I962) showed that certain decomposition products of lignin are capable of preventing spore germination.

There is no direct evidence that nutrients in spore exudates, or nutrient levels generally present in soil can provide the energy required for the synthesis of inhibitors. Bacteria and actinomycetes inhibited germination of nutrient-independent spores, but membranesterilized filtrates of the mixtures were not inhibitory when reinoculated with test fungi (Lingappa \& Lockwood, I964; Blakeman \& Fraser, 197I). However, such a possibility may be suggested by the results of Jackson \& Knight (I973) who found that ${ }^{14} \mathrm{C}$-labelled conidia of C. sativus were more strongly inhibited when incubated on dialysis tubing containing a soil suspension than on dialysis tubing containing water, though loss of label to water was greater.

Several lines of evidence from this or other research indicate that the microbial nutrient sink alone can account for the inhibition in Conover loam. Among these are the near instantaneous establishment of the microbial energy sink, and several correlations of results obtained with soil and the leaching system, namely: (i) the similarity of the fungistatic spectrum, as it affects nutrient-independent propagules, and the ability of ascospores of $N$. tetrasperma to germinate on either system (Ko \& Lockwood, 1967; Hsu \& Lockwood, 1973); (ii) similarly increased germination of $C$. victoriae conidia on both systems after brief exposure to water (Table I); (iii) the similarity in the expression of fungistasis using agar or polyacrylamide gel discs (Table 2); (iv) the similarity in degree of annulment of fungi- 
stasis by nutrients (Table 3 ); (v) the very similar rates at which conidia of $C$. victoriae and Cochliobolus sativus were converted to nutrient-dependency (Bristow \& Lockwood, 1975); (vi) the very similar rates of reversal in the progress towards germination made by conidia of Penicillium frequentans, when subsequently incubated in either system (Yoder \& Lockwood, 1973). That enforced inactivity as a result of intense competition for scarce nutrients is the rule for micro-organisms in soil is also indicated from calculations of the yearly input of energy substrate to soil in relation to the biomass that must be supported. The energy available after cell maintenance requirements are met, would allow cells to divide only a few times per year (Babiuk \& Paul, I970; Gray \& Williams, I97I).

The presence of inhibitory volatile materials emanating from the alkaline clay loam soil was readily shown. Moreover, in contrast with Conover loam, the clay loam showed persistent suppression of conidia previously incubated on moist sand, utilized energy sources more slowly, showed only partial annulment of fungistasis by glucose or soil sterilization, and inhibited germination of ascospores of $N$. tetrasperma.

It was concluded that nutrient deprivation resulting from the microbial nutrient sink is the factor primarily responsible for fungistasis in Conover loam soil, and that fungistatic substances in the alkaline clay loam soil not only inhibit germination directly, but reduce the microbial competition in that soil as well.

Journal article No. 7I26 from the Michigan Agricultural Experiment Station. We thank R. Baker for the gift of alkaline clay loam soil.

\section{REFERENCES}

Adams, P. B., Lewis, J. A. \& Papavizas, G. C. (I968). Survival of root-infecting fungi in soil. IV. The nature of fungistasis in natural and cellulose-amended soil on chlamydospores of Fusarium solani f.sp. phaseoli. Phytopathology 58, 378-383.

BabiuK, L. A. \& PaUL, E. A. (1970). The use of fluorescein isothiocyanate in the determination of the bacterial biomass of grassland soil. Canadian Journal of Microbiology 16, 57-62.

Bishop, D. H., ClaYBRoOK, J. R. \& SPiegelman, S. (1967). Electrophoretic separation of viral nucleic acids on polyacrylamide gels. Journal of Molecular Biology 26, 373-387.

Blakeman, J. P. \& Fraser, A. K. (1971). Inhibition of Botrytis cinerea spores by bacteria on the surface of chrysanthemum leaves. Physiological Plant Pathology 1, 45-54.

Bray, G. A. (1960). A simple efficient liquid scintillator for counting aqueous solutions in a liquid scintillation counter. Annals of Biochemistry I, 279-285.

Bristow, P. R. \& Lockwood, J. L. (1975). Soil fungistasis: role of spore exudates in the inhibition of nutrient-independent propagules. Journal of General Microbiology 90, 140-146.

FARLEY, J. D. \& LocKWOOD, J. L. (1968) The suppression of actinomycetes by PCNB in culture media used for enumerating soil bacteria. Phytopathology 58, 714-715.

Gray, T. R. G. \& Williams, S. T. (197I). Microbial productivity in soil. In Microbes and Biological Productivity, pp. 255-286. Edited by D. E. E. Hughes and A. H. Rose. Cambridge University Press.

HoRA, T. S. \& BAKER, R. (1970). A volatile factor in soil fungistasis. Nature, London 225, 1071-1072.

Hsu, S. C. \& LockwOOD, J. L. (I973). Soil fungistasis: behaviour of nutrient-independent spores and sclerotia in a model system. Phytopathology 63, 334-337.

JACKsON, R. M. \& KNIGHT, R. A. (1973). Conidial germination of Cochliobolus sativus on soil and under artificial nutrient stress. Abstracts of Papers, Second International Congress of Plant Pathology. Minneapolis: University of Minnesota.

Ko, W. H., Hora, F. K. \& HerlicsKa, E. (1974). Isolation and identification of a volatile fungistatic substance from alkaline soil. Phytopathology 64, $1398-1400$.

Ko, W. H. \& Lockwood, J. L. (1967). Soil fungistasis: relation to fungal spore nutrition. Phytopathology 57, $894-901$.

LiNGAPPA, B. T. \& LockwOod, J. L. (1962). Fungitoxicity of lignin monomers, model substances, and decomposition products. Phytopathology 52, 295-299. 
LingaPPA, B. T. \& Lockwood, J. L. (1964). Activation of soil microflora by fungus spores in relation to soil fungistasis. Journal of General Microbiology 35, 215-277.

LingaPPA, Y. \& Lockwood, J. L. (1962). Chitin media for selective isolation of actinomycetes. Phytopathology 52, 3I7-323.

Smith, A. M. (1973). Ethylene as a cause of soil fungistasis. Nature, London 246, 3I I-3I 3.

Steiner, G. W. \& Lockwood, J. L. (I969). Soil fungistasis: sensitivity of spores in relation to germination time and size. Phytopathology 59, $1084-1092$.

Steiner, G. W. \& Lockwood, J. L. (1970). Soil fungistasis: mechanism in sterilized, reinoculated soil. Phytopathology 60, 89-9I.

SteineR, G. W. \& Watson, R. D. (1965). Use of surfactants in the soil dilution and plate count method. Phytopathology 55, 728-730.

YoDer, D. L. \& LockWOod, J. L. (1973). Fungal spore germination on natural and sterile soil. Journal of General Microbiology 74, 107-I I 7. 